\title{
ANATOMICAL STUDIES OF IN VITRO ORGANOGENESIS INDUCED IN LEAF-DERIVED EXPLANTS OF PASSIONFRUIT ${ }^{1}$
}

\author{
BEATRIZ APPEZZATO DA GLORIA ${ }^{2}$, MARIA LUCIA CARNEIRO VIEIRA ${ }^{3}$ and MARCELO CARNIER DORNELAS ${ }^{4}$
}

\begin{abstract}
With the aim of studying the organogenesis in vitro in Passiflora edulis Sims f. flavicarpa Deg., the passionfruit, leaf-derived explants were cultured on media containing NAA or BAP and incubated either in continuous darkness or in light. The histological events leading to de novo organ formation were evaluated. Darkness induces rhizogenesis in the presence of NAA, whereas direct shoot regeneration is stimulated by light and BAP. This latter condition is recommended for passionfruit micropropagation as several adventitious shoot buds were formed from meristemoids of parenchymal origin.
\end{abstract}

Index terms: Passiflora, tissue culture, micropropagation, histology.

\section{ESTUDOS ANATÔMICOS DA ORGANOGÊNESE IN VITRO INDUZIDA EM EXPLANTES DE FOLHA DE MARACUJÁ}

\begin{abstract}
RESUMO - Com o objetivo de estudar a organogênese in vitro em Passiflora edulis Sims f. flavicarpa Deg., o maracujá-amarelo, explantes derivados de folha foram cultivados em meio contendo NAA ou $\mathrm{BAP}$, no escuro e na presença de luz. Foram descritos os eventos histológicos que levam à formação de novo de órgãos. Concluiu-se que o escuro induz a rizogênese, na presença de NAA, enquanto a regeneração de brotos é estimulada pela luz e BAP. Esta condição é recomendada para micropropagar o maracujá uma vez que vários brotos adventícios são formados a partir de meristemóides de origem parenquimática.

Termos para indexação: Passiflora, cultura de tecidos, micropropagação, histologia.
\end{abstract}

\section{INTRODUCTION}

Passionfruit (Passiflora edulis Sims f. flavicarpa Deg.) is one of the most economically important fruit crop used in Brazil for juice processing. Although passionfruit is cultivated in a relatively large area $(30,000 \mathrm{ha})$, little production is in organized orchards. Flowers are hermaphrodites and insect-pollinated, although a simple hand pollination

${ }^{1}$ Accepted for publication on November 16, 1998

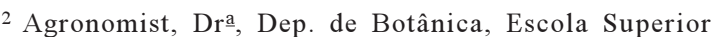
de Agricultura Luiz de Queiroz (ESALQ), USP, Caixa Postal 9, CEP 13418-900 Piracicaba, SP. E-mail: bagloria@carpa.ciagri.usp.br

${ }^{3}$ Biologist, Livre Docente, Dep. de Genética, ESALQ, USP. E-mail: mlcvieir@carpa.ciagri.usp.br

${ }^{4}$ Agronomist, M.Sc., Instituto de Biotecnologia de Plantas, Universidade de Paris XI, 91405 Orsay, França. CAPES scholar. technique is often used to enhance productivity. Passiflora species are normally propagated from seeds and cuttings.

Passiflora micropropagation has been described by Moran Robles (1978) and recently by Kantharajah \& Dodd (1990) and Kawata et al. (1995). Plant regeneration from tissue culture has also been reported from a diversity of Passiflora germplasm, including the cultivated species (Dornelas \& Vieira, 1994). Regeneration occurred by organogenesis on the surface of the explants.

Micropropagation offers the possibility of large scale multiplication of plant material. The propagative potential depends on the species and on the explant source. In Passiflora edulis f. flavicarpa, for example, an average of 57 shoots could be produced from one cotyledon-derived explant. Meanwhile, using the same culture medium, an average of 18 and 46 shoots could be obtained per hypocotyl and leaf explants, respectively. Compared with these 
numbers, micropropagation by cuttings has a relatively low multiplication rate. For commercial application, high rates of shoot development are required. Regeneration rates (percentage of explants that produced shoots) varied from $70 \%$ in the wild species up to $96 \%$ in Passiflora edulis f. flavicarpa (Dornelas \& Vieira, 1994).

Meristem-derived cultures without a significant dedifferentiation step give rise to normal plants. Among those types of cultures that regenerate after a dedifferentiated (callus) phase, one can distinguish between regeneration by organogenesis or somatic embryogenesis. It is clear from histological studies that organogenesis often involves more than one cell that act in a coordinate manner (Brown \& Thorpe, 1986). In the case of somatic embryogenesis, the embryoid is often derived from a single cell, although evidence for a multicellular origin has also been obtained (Dornelas et al., 1992).

Some authors have argued that plants regenerated from direct somatic embryogenesis even by direct organogenesis ought to contain fewer mutations than those regenerated via callus phase. Also, many investigators have noted an increase in variability with an increase in culture age (Lee \& Phillips, 1987).

Our studies on species of Passiflora showed that plant regeneration occurs via direct organ differentiation after a short culture period of 28 days. These cultures have been able to produce viable plants by subsequent rooting (Dornelas \& Vieira, 1994). However, the occurrence of direct organogenesis has to be clearly demonstrated by anatomical evidence.

Thus, the present work focuses on the sequences of events, specially at the anatomical level, leading to the process of passionfruit plant regeneration. This investigation also deals with the effects of two light regimes and different hormone treatments on this process.

\section{MATERIALAND METHODS}

The experiments were carried out at Escola Superior de Agricultura Luiz de Queiroz, at Piracicaba, Brazil, during the year of 1994. The protocol for obtaining de novo organ formation consisted of culturing leaf explants on MS basal medium (Murashige \& Skoog, 1962) containing $0.3 \%(\mathrm{w} / \mathrm{v})$ sucrose and supplemented with $1.0 \mathrm{mg} \mathrm{L}^{-1} \mathrm{BAP}$ (6-benzyl aminopurine) or $1.0 \mathrm{mg} \mathrm{L}^{-1} \mathrm{NAA}$ (1-naphthaleneacetic acid). As reported previously, these growth regulator concentrations lead to in vitro regeneration of shoots and roots, respectively (Dornelas \& Vieira, 1994). The media were solidified with $0.15 \%$ Phytagel (w/v, Sigma) and distributed (10 mL per flask) into $25 \times 85 \mathrm{~mm}$ flasks, which were autoclaved for 20 minutes. The $\mathrm{pH}$ was adjusted to 5.8 prior to adding the gelling agent.

Leaf explants of $P$. edulis f. flavicarpa were excised from 60-day-old plants as described by Dornelas \& Vieira (1994). The explants were taken from the central part of the leaves, thus containing the midrib. Using a cork-borer (11 $\mathrm{mm}$ in diameter) 48 discs (6 treatments $\mathrm{x} 4$ culture conditions x 2 replicates) were halved and placed individually into the flasks that were sealed with plastic film.

In order to study the influence of light regime in the process of in vitro regeneration the cultures were grown either under $23 \mu \mathrm{mol} \mathrm{m} \mathrm{m}^{-2}$ second $^{-1}$ light radiation (16 hours photoperiod) provided by a cold-white bulb $(80 \mathrm{~W})$, or darkness. The temperature of the culture room was kept at $25 \pm 2^{\circ} \mathrm{C}$

Leaf explants samples were collected after $0,3,7,14$, 21 and 28 days of culture. Samples were collected from the four culture conditions, raised from the combinations of MS $+1.0 \mathrm{mg} \mathrm{L}^{-1}$ of BAP or NAA and the two light regimes.

Samples were fixed in FAA 50, dehydrated in an ethanol series, embedded in paraffin, serially cut into $8 \mu \mathrm{m}$ sections (Sass, 1951) and stained in basic fuchsin-astra blue combination (Roeser, 1972).

\section{RESULTS AND DISCUSSION}

\section{Explant characterization}

Analysis of cross sections of P. edulis $\mathrm{f}$. flavicarpa collected at the beginning of in vitro culture (day 0) revealed that the leaf is hypostomatic. In the lamina the outermost layer of cells (epidermis) is uniseriate and establishes the limits of the dorsiventral mesophyll. The latter consists of uniseriate palisade parenchyma with short non-juxtaposed cells and of spongy parenchyma with two to three layers of weakly arranged cells. The presence of collateral vascular bundles limited by a parenchymatic bundle with or without extension, can be seen along with the mesophyll. The midrib 
presents the vascular system with four collateral bundles arranged in a circle and enclosed by the fundamental parenchyma. This characterization confirms the data presented by Abanto \& Müller (1972) for P. edulis leaf anatomy.

The explants did not present any anatomical changes after three days. In contrast, Moran Robles (1979) and Scorza \& Janick (1980) reported changes in the internal structures of the stem segments of $P$. edulis and $P$. suberosa L., cultivated during the same period on Nitsch medium (Nitsch et al., 1968) supplemented with $2.0 \mathrm{mg} \mathrm{L}^{-1}$ kinetin and on MS containing $0.1 \mathrm{mg} \mathrm{L}^{-1}$ 6-benzylaminopurine, respectively. According to the investigators, proliferation of large cells with a prominent nucleus was observed in the sectioned areas. Usually, these cells originated from cortical tissue. This pattern was not observed in this study.

Explants cultivated on $\mathrm{MS}+\mathbf{1 . 0} \mathrm{mg} \mathrm{L}^{-1} \mathrm{BAP}$, under $23 \mu \mathrm{mol} \mathrm{m}{ }^{-2}$ sec $^{-1}$ light radiation

Plant tissue culture systems offer the possibility of analyzing the point of determination of cytodifferentiation (Fukuda \& Komamine, 1985). Under these conditions (light and BAP stimulus), the explants presented alterations in the leaf border region after the $7^{\text {th }}$ day of culture. The mesophyll displayed small cells with a dense cytoplasm and conspicuous nucleus originated from the chlorophyll parenchyma, associated or not with the explant vascularisation. The first divisions in the fundamental parenchyma of the midrib were also observed during this phase.

On the $14^{\text {th }}$ day of culture, the palisade parenchyma presented more elongated cells in some of the mesophyll sectors. Predominantly periclinal divisions in the mesophyll close or not to the vascularisation were observed in other sectors. The divisions in the more peripheral layers led to the formation of meristematic areas (Fig. 1A) similar to those described by Saravitz et al. (1993) as meristemoids. These consisted of small cells with a dense cytoplasm and prominent nucleus. At the same time, divisions on several planes were observed in the fundamental parenchyma on the adaxial surface of the midrib, especially in the subepidermal layers, which led to the formation of meristematic structures similar to those described for the mesophyll.

On the $21^{\text {st }}$ day of culture, these structures were more developed and were found to be lined with the protodermis of epidermal origin (Fig. 1B, arrow), as also occurs in Pinus radiata (Villalobos et al., 1985) and Picea abies (Von Arnold et al., 1988). During this phase, there was an increased activity of the fundamental parenchyma leading to disorganization of the vascular system of the midrib, which progressed with culture (Fig. 1C). The presence of several shoot buds in different developmental phases (Fig. 1C and 1D) was observed on the $28^{\text {th }}$ day, confirming that these buds originated from the meristematic structures described. The absence of synchrony in bud formation was also noted by Von Arnold et al. (1988) and Saravitz et al. (1993).

Thus, the adventitious shoot buds of $P$. edulis $\mathrm{f}$. flavicarpa were developed from meristemoid areas after the second week of culture, as the result of the mitotic activity of parenchymatous cells, given support to the results reported by Scorza \& Janick (1980) for P. suberosa. The predominance of cell divisions in the explant epidermis and subjacent layers in response to BAP has been observed in conifers (Villalobos et al., 1985; Von Arnold \& Gronroos, 1986; Saravitz et al. 1993). In Begonia $\mathbf{x}$ erythrophyla petiole sections both shoots and roots are formed directly from cells of epidermal origin (Burritt \& Leung, 1996). Yeung et al. (1981) suggested that the epidermal and subjacent layers are not completely determined at the time of excision, leading these cells to respond to cytokinin stimulus.

\section{Explants cultivated on MS $+1.0 \mathrm{mg} \mathrm{L}^{-1} \mathbf{B A P}$, in the dark}

Structural alterations were first observed after two weeks of culture in contrast of cultures maintained in the light, which already showed meristematic structures at this time. Elongation of the palisade parenchyma cells was observed in the leaf lamina and progressed with culture age. This elongation was more pronounced than that observed under light. This phase was characterized by the beginning of 
meristematic activity under the stomata, which persisted during the course of culture. In embryos of Picea abies treated with BAP the surrounding cells of stomata started to proliferate and meristemoid cells developed during the second week of culture (Von Arnold et al., 1988). Barciela \& Vieitez (1993) also reported the morphogenetic potential of the adaxial epidermis of Camellia cotyledons. These data support the results of Kaneko \& Matsushima (1984) in stem segments of Nicotiana tabacum although no development of shoot buds from the cell proliferation was observed in this material.

Divisions in several planes of the fundamental parenchyma were observed and became more intense on the $21^{\text {st }}$ and $28^{\text {th }}$ day of culture.
However, the development of meristemoid areas was not observed.

The relationship between morphogenetic ability and light regime has been reported in the literature. The exhaustive study carried out by Seibert et al. (1975) showed the effects of light intensity and spectral quality on callus formation and bud regeneration in tobacco explants. These investigators observed that light contributed to an increase in the callus fresh matter weight and in the number of regenerated buds, comparing to cultures maintained in the dark. Previously, Weiss \& Jaffe (1969) had described the stimulating effects of blue light on the process of organogenesis in tobacco apex cultures. Moran Robles (1979) also reported the influence of

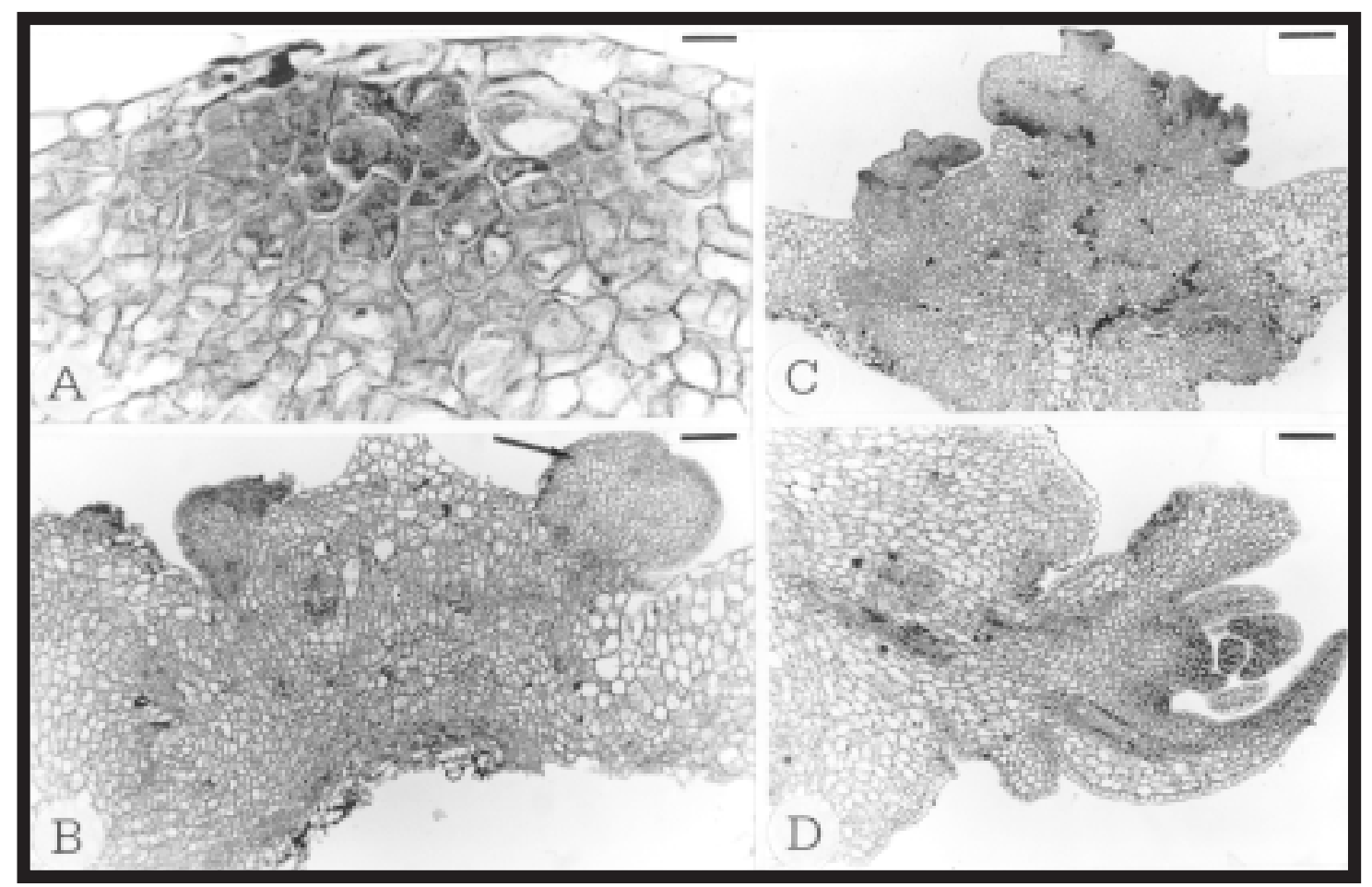

FIG. 1. Transections of a leaf explant of Passiflora edulis $\mathrm{f}$. flavicarpa placed on MS medium supplemented with $1.0 \mathrm{mg} \mathrm{L}^{-1}$ BAP under $23 \mu \mathrm{mol} \mathrm{m}^{-2}$ second $^{-1}$ light radiation, after 14 (A), 21 (B) and 28 (C, D) days of culture. A: Detail of the divisions in the subepidermal layers that led to the formation of meristemoid areas $(\mathrm{bar}=\mathbf{2 5} \boldsymbol{\mu m})$. B: The arrow indicates a meristematic structure originated from the meristemoids $(\mathrm{bar}=230 \mu \mathrm{m})$. C: Midvein exhibiting the disorganized vascular system resulting from the intense meristematic activity and the presence of shoot buds $($ bar $=290 \mu \mathrm{m})$. D: Detail of a shoot bud $($ bar $=100 \mu \mathrm{m})$. 
luminosity in the number of growing shoots in Passiflora cultures comparing to explants kept in the dark.

Explants cultivated on MS $+1.0 \mathrm{mg} \mathrm{L}^{-1} \mathrm{NAA}$

The first explant alterations promoted by the NAA treatment in cultures maintained under light started on the $14^{\text {th }}$ day. Divisions on several planes were observed in the fundamental parenchyma of the midrib and leaf border. However, neither the increase in the meristematic activity nor the root meristemoid formation usually stimulated by an auxin were observed during the course of this type of culture.

In the dark, the first anatomical changes relating to organogenesis were observed on the $21^{\text {st }}$ day of culture. In the mesophyll, the cells of the palisade parenchyma divided periclinally and the spongy parenchyma cells divided along several planes. In the midrib, root meristemoids developed from meristematic activity initiating near the procambium of the midvein vascular system (Fig. 2A and 2B, arrows). Moran Robles (1979) also observed rhizogenesis in internodal explants of $P$. edulis var. flavicarpa Deg. and P. mollissima Bailey, after the $21^{\text {st }}$ day of culture.

By the $28^{\text {th }}$ day of culture, in addition to the adventitious roots developed in the midrib, several roots were observed along the mesophyll. The formation of these structures was endogenous and always associated with the explant vascularisation (Fig. 2C and 2D, arrows). As proposed before, the sites of origin of adventitious roots have been located in cells of the procambium or close to it, in the phloem (Hicks, 1987; Ranjit et al., 1988).

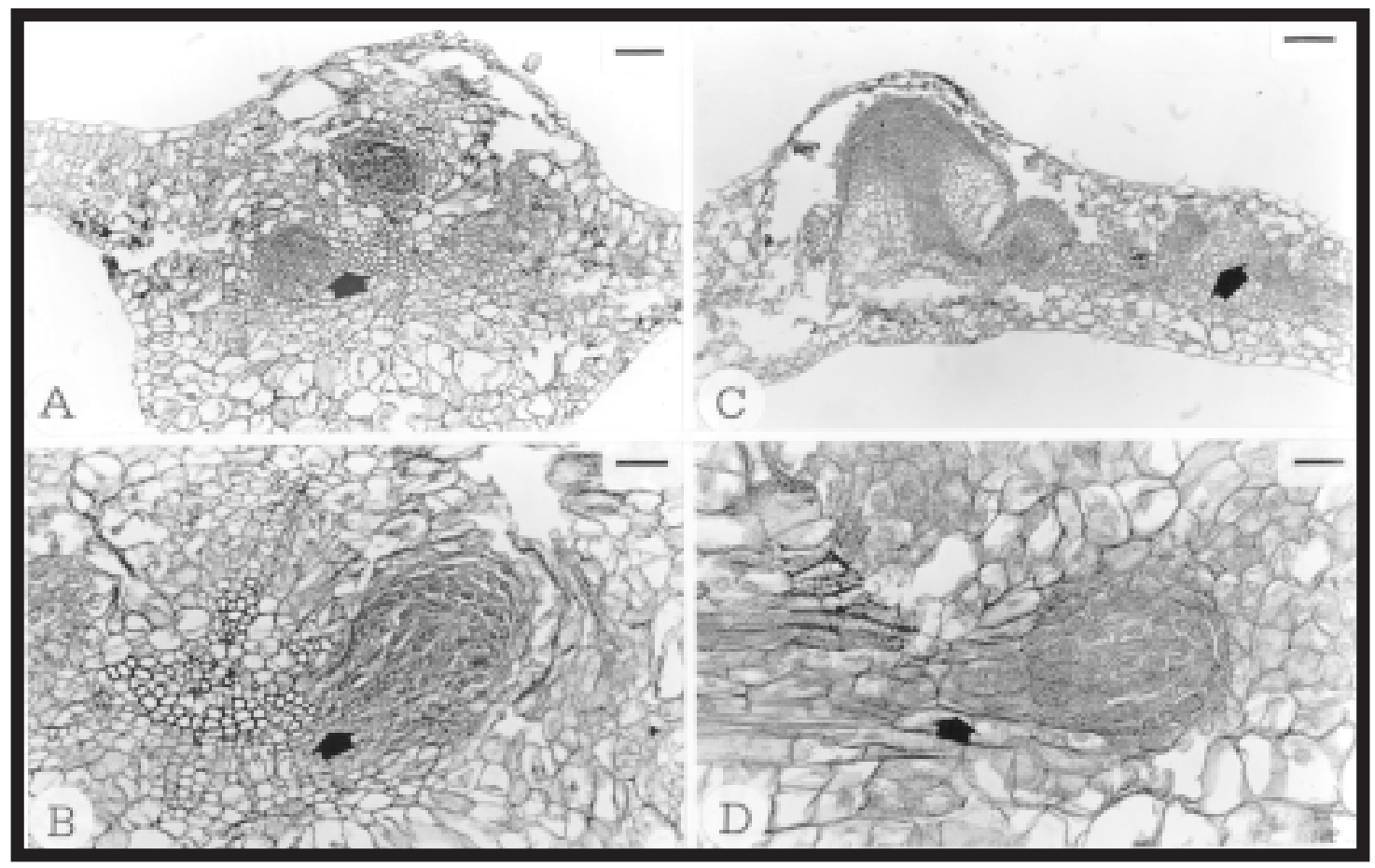

FIG. 2. Transections of a leaf explant of Passiflora edulis $\mathrm{f}$. flavicarpa placed on MS medium supplemented with $1.0 \mathrm{mg} \mathrm{L}^{-1}$ NAA cultured in the dark, after 21 (A, B) and $28(C, D)$ days. A and B: The arrows indicate the formation of a root meristemoid from divisions in the procambium of the midvein vascular system (bar $=100$ and $52 \mu \mathrm{m}$, respectively). $C$ and $D$ : Root meristemoids and adventitious roots developing along the mesophyll, always associated with the explant vascularisation (arrows; bar $=100$ and $26 \mu \mathrm{m}$, respectively). 
Harbage et al. (1993) by inducing rhizogenesis in Malus observed that cells of several tissues divided in response to IBA treatment but, only divisions in the phloem parenchyma led to the development of adventitious roots. Similarly, adventitious root formation observed in the present study occurred near the explant vascularisation although the chlorophyll parenchyma showed divisions on several planes.

\section{CONCLUSIONS}

1. Leaf explants of P. edulis f. flavicarpa exhibit distinct morphogenic reactions as a function of the hormone added to the culture medium and are highly responsive and become strongly determined by the $28^{\text {th }}$ day of culture.

2. Rhizogenesis occurs in the presence of NAA whereas direct shoot regeneration is stimulated by BAP.

3. The white light is essential for bud formation in leaf-derived explants cultured on medium supplemented with BAP.

4. The dark condition acts synergistically with the effect of auxin leading to adventitious root formation

\section{ACKNOWLEDGEMENTS}

To the Conselho de Desenvolvimento Científico e Tecnológico (CNPq) and the Fundação de Amparo à Pesquisa do Estado de São Paulo (FAPESP) for financial support; to Mr. C. A. de Oliveira and Mrs. M. A. R. Machado for excellent technical assistance.

\section{REFERENCES}

ABANTO, A.M.; MÜLLER, L. Algunos aspectos morfológicos del maracuyá, Passiflora edulis. Turrialba, v.22, p.268-274, 1972.

BARCIELA, J.; VIEITEZ, A.M. Anatomical sequence and morphometric analysis during somatic embryogenesis on cultured cotyledon explants of Camellia japonica L. Annals of Botany, Oxford, v.71, p.395-404, 1993.

BROWN, D.C.W.; THORPE, T.A. Plant regeneration by organogenesis. In: VASIL, I. K. (Ed.). Cell culture and somatic cell genetics of plants. Orlando: Academic, 1986. v.3, p.49-73.

BURRITT, D.; LEUNG, D.W.M. Organogenesis in cultured petiole explants of Begonia x erythrophylla: the timing and specificity of the inductive stimuli. Journal of Experimental Botany, Oxford, v.47, p.557-567, 1996.

DORNELAS, M.C.; VIEIRA, M.L.C.; GLÓRIA, B.A. da. Histological analysis of organogenesis and somatic embryogenesis induced in immature tissues of Stylosanthes scabra Vog. Annals of Botany, Oxford, v.70, p.477-482, 1992.

DORNELAS, M.C.; VIEIRA, M.L.C. Tissue culture studies on species of Passiflora. Plant Cell, Tissue and Organ Culture, Dordrecht, v.36, p.211-217, 1994.

FUKUDA, H.; KOMAMINE, A. Cytodifferentiation. In: VASIL, I.K. (Ed.). Cell culture and somatic cell genetics of plants. Orlando: Academic, 1985. v.2, p.149-212

HARBAGE, J.F.; SIMART, D.P.; EVERT, R.F. Anatomy of adventitious root formation in microcuttings of Malus domestica Borkh. "Gala". Journal of the American Society for Horticultural Science, Geneva, v.118, p.680-688, 1993.

HICKS, G.S. Adventitious rooting of apple microcuttings in vitro: an anatomical study. Canadian Journal of Botany, Ottawa, v.65, p.1913-1920, 1987.

KANEKO, Y.; MATSUSHIMA, H. Direct observation by low-temperature scanning electron microscopy of fresh-shoot apices and floral buds induced to form on Nicotiana tabacum stem cultures. Journal of Electron Microscopy, Tokyo, v.33,p.248-251, 1984.

KANTHARAJAH, A.S.; DODD, W.A. In vitro micropropagation of Passiflora edulis (Purple passionfruit). Annals of Botany, Oxford, v.65, p.337-339, 1990.

KAWATA, K.; USHIDA, C.; KAWAI, F.; KANAMORI, M.; KURIYAMA, A. Micropropagation of passion fruit from subcultured multiple shoot primordia. Journal of Plant Physiology, Stuttgart, v.147, p.281-284, 1995. 
LEE, M.; PHILLIPS, R. L. Genomic rearrangements in maize induced by tissue culture. Genome, Ottawa, v.29, p.122-128, 1987.

MORAN ROBLES, M.J. Multiplication végétative, in vitro, des bourgeons axilaires de Passiflora edulis var. flavicarpa Deg. et de P. mollissima Bailey. Fruits, Paris, v.33, p.693-699, 1978.

MORAN ROBLES, M.J. Potentiel morphogénétique des entrenoeuds de Passiflora edulis var.flavicarpa Deg et $P$. mollissima Bailey en culture in vitro. Turrialba, v.29, p.224-228, 1979.

MURASHIGE, T.; SKOOG, F. A revised medium for rapid growth and bioassays with tobacco tissue cultures. Physiologia Plantarum, Kobenhavn, v.15, p.473-497, 1962.

NITSCH, J.; NITSCH, C; HAMON, S. Réalisation expérimentale de l'androgénèse chez divers Nicotiana. Comptes Rendus de la Societé de Biologie, Paris, v.162, p.369-372, 1968.

RANJIT, M.; KESTER, D.E.; POLITO, V.S. Micropropagation of cherry rootstocks: III. Correlations between anatomical and physiological parameters and root initiation. Journal of the American Society for Horticultural Science, Geneva, v.113, p.155-159, 1988.

ROESER, K.R. Die Nadel der Schwarzkiefer - Massen Produkt und Kunstwert der Natur. Mikrokosmos, Stuttgart, v.61, p.33-36, 1972.

SARAVITZ, C.H.; BLAZICH, F.A.; AMERSON, H.V. Histology of in vitro adventitious bud development on cotyledons and hypocotyls of Fraser fir. Journal of the American Society for Horticultural Science, Geneva, v.118, p.163-167, 1993.
SASS, J.E. Botanical microtechnique. Ames: Iowa University Press, 1951. 228p.

SCORZA, R.; JANICK, J. In vitro flowering of Passiflora suberosa L. Journal of the American Society for Horticultural Science, Geneva, v.105, p.892-897, 1980

SEIBERT, M.; WETHERBEE, P.J.; JOB, D.D. The effects of light intensity and spectral quality on growth and shoot initiation in tobacco callus. Plant Physiology, Rockville, v.56, p.130-139, 1975.

VILLALOBOS, V.M.; YEUNG, E.G.; THORPE, T.A. Origin of adventitious shoots in excised radiata pine cotyledons cultured in vitro. Canadian Journal of Botany, Ottawa, v.63, p.2172-2176, 1985.

VON ARNOLD., S.; GRONROOS, R. Anatomical changes and peroxidase activity after cytokinin treatments inducing adventitious bud formation on embryos of Picea abies. Botanical Gazette, Chicago, v.147, p.425-431, 1986

VON ARNOLD, S.; ALSTERBORG, E.; WALLES, B Micromorphological studies of adventitious bud formation on Picea abies embryos treated with cytokinin. Physiologia Plantarum, Kobenhavn, v.72, p.248-256, 1988.

WEISS, J.F.; JAFFE, M.J. Photoenhancement by blue light of organogenesis in tobacco pith cultures. Physiologia Plantarum, Kobenhavn, v.22, p.171-176, 1969.

YEUNG, E.C.; AITKEN, J.; BIONDI, S.; THORPE, T.A. Shoot histogenesis in cotyledon explants of radiata pine. Botanical Gazette, Chicago, v.142, p.494-501, 1981. 